\title{
Fundamental Anomalies and Firms Financial Distress; Evidence from Nairobi Securities Exchange, Kenya
}

\author{
Roche Charles', Dr. Olweny Tobias ${ }^{2}$ and Dr. Nasieku Tabitha ${ }^{3}$
}

\begin{abstract}
Stock market broadly referred to as security exchange has gained so much interests from various stakeholders around the world as they endow exceedingly to the growth of the world economy. Nairobi Securities Exchange, being an emerging stock market, this study therefore considered dividend yield anomaly, measured by dividend per share and price to earnings anomaly operationalized through earnings per share as the types of the fundamental anomalies. When there is fundamental anomaly, firms tend to exhibit unhealthy financial position which is financial distress, measured by Z-Score. The main objective of this study is to examine the relationship between fundamental anomalies and firms' financial distress; evidence from Nairobi Securities Exchange, Kenya. This study adopts descriptive research design and embraced secondary data from 2007 to 2017 from a target population of 67 listed firms. It was found that there existed a relationship between fundamental anomalies and firms' financial distress. The study recommends that the management should put in place the right dividend policies, declaration or nondeclaration of dividends in the treatment of dividends. For policy makers and regulators, the recommendations will assist in restoring law and order and this will enable all the stakeholders to have confidence in Nairobi Securities Exchange.
\end{abstract}

Keywords: Securities Exchange, Financial Distress, Fundamental Anomalies.

\footnotetext{
1 Department of Economics, Accounting and Finance, School of Business, Jomo Kenyatta University of Agriculture and Technology.

2 Post Graduate Coordinator, Department of Economics, Accounting and Finance, School of Business, Jomo Kenyatta University of Agriculture and Technology.

3 Chair, Department of Economics, Accounting and Finance, School of Business, Jomo Kenyatta University of Agriculture and Technology.
} 


\section{Introduction}

Stock market broadly referred to as security exchange has gained so much interests from various stakeholders around the world as they endow exceedingly to the growth of the world economy. Stocks are categorized as a security that represents ownership interest in a firm. Securities are tradeable financial assets which are grouped into equity securities referred to as stocks, debt securities, also known as bonds and derivative securities. Securities can be traded on an exchange like the Nairobi Securities Exchange or over the counter. As an economic institution, stock market performs an important responsibility in the economy which improves the effectiveness in capital origination and allotment, (Olweny \& Kimani, 2011). Stock market therefore serves an as economic tool for mobilization and allocation of investments amidst competing utilities as these utilities are very important to the advancement and efficacy of the economy, (Alile, 1984).

Stock trading therefore permits firms to raise capital to settle debts, launch contemporary products and enlarge if not diversify its operations. For investors, stocks give the opportunity to profit from yields in stock value in addition to company dividend payments. Stock market therefore afford the listed firms with a podium to step-up long term capital and in addition to presenting the investors with alternate investments, (Olweny \& Kimani, 2011). Thus, stock market ought to be efficient as this efficiency is very important in determination of the overall economy growth, (Alile, 1984).

According to Bloomfield (2010), anomalies are observations which are inconsistent with the paradigm. Santos (2011), defines anomalies as forms of judgments and choices that are not consistent with utility maximization. A market anomaly is at times referred to as an inefficient market. This is when the price or return rate is distorted on a financial market and contradicts the Efficient Market Hypothesis (EMH). Market anomaly mostly associates with structural factors such as unjust regulatory actions, competition and no transparency in the market. There are different types of market anomalies such as fundamental, technical, seasonal and size effect anomalies. This study picks on the fundamental anomalies which forms part and parcel of this study. Fundamental anomaly is one of the anomalies which affect the financial wellbeing of firms.

Fundamental anomalies indicate that the prices of securities do not entirely reflect their intrinsic values, (Karz, 2010). When market price of stocks do not follow the principle of supply and demand, then we have fundamental anomaly. Generally speaking, types of fundamental anomalies are; value anomalies and small cap effect, low price to book (P/B), high dividend yield, low price to sales $(\mathrm{P} / \mathrm{S})$, low price to earnings $(\mathrm{P} / \mathrm{E})$, value versus growth anomaly, overreaction anomaly and neglected stocks, (Karz, 2010). The Nairobi Securities Exchange being an emerging stock market, this study therefore restricts itself to the dividend yield and price to earning anomalies as the types of fundamental anomalies.

The dividend yield will rise when the price of the stock falls and falls when the price of the stock rises. By the virtue that dividend yield change is comparative to the 
stock price, it can often look unusually high for stocks that are falling in value quickly. Dividend yield anomaly comes about when high dividend yield stocks outmaneuver the market in performance. The opposite is true as low dividend yield underachieves than the market in performance. With price to earnings anomaly, stocks having low price to earnings ratio outrun stocks with high price to earnings and vice versa, (Karz, 2010).

According to Adeyemi, (2011), financial distress is a circumstance when a firm is experiencing difficulties in its operations, management and finances. Wruck (1990), financial distress in a firm can be detected by the dividends of the firm. Another good indicator of financial distress is the slip of the levels of dividends issued out or when the dividends are not issued at all. Thus, financial distress position of a firm is a state that will drastically reduce its market value in the stock market, (Baimwera \& Muriuki, 2014). The financial distress can also refer to bankruptcy, insolvency, failure or default.

Financial distress affects the survival of firms listed in the stock market as these firms face restructures, being put under receivership, suspension or possibly delisted from the stock markets. Globally all stakeholders are mostly concerned with the financial health of listed firms in the stock markets, (Altman \& Hotchkiss, 2010). This has then rendered the stock market as a tool which is very effective for economy development of any nation. Thus, stock market is a suitable device for mobilizing and allocating savings amid rival uses that are imperative to the advancement and effectiveness in the economy, (Olweny \& Kimani, 2011).

Therefore, it is evident that when there is fundamental anomaly, then firms tend to exhibit financial distress. Thus fundamental anomaly and financial distress have a relationship. This link was discussed by Avramov, Chordia, Jostova and Philipov (2013); who stated that importantly to note is the financial distress and not poor performance which is depicted through falling stock prices that impacts the fundamental anomaly. Finding out the link which exists in this relationship will be a sigh of relieve to all the stakeholders, (Baimwera \& Muriuki, 2014). According to Avramov et al. (2013), it was discovered that companies with high credit risk ZScore reach a minimum downgrade to capture financial distress.

\subsection{Statement of the Problem}

Financial distress takes a lion's share of challenges which firms listed in the Nairobi Securities Exchange are exposed to in their day to day operations. According to Arnold (2016), the effects of financial distress are so severe to the operations of a firm and its environment which consists of stockholders, credit institutions, investors, management, employees and a whole economy. In Kenya, about 53\% of the firms listed in the Nairobi Securities Exchange are financially distressed, (Maina \& Sakwa, 2012). Kenya has seen 21 listed firms which undertook financial restructure, put under receivership, suspended or delisted from the Nairobi Securities Exchange due to financial distress since independence (CMA, 2014). This study attempts to ascertain if the fundamental anomalies have a significant 
relationship with financial distress, (Elena-Dena \& Iona-Christina, 2013).

\subsection{Objectives of the Research}

The main objective of this study is to examine the relationship between fundamental anomalies and firms' financial distress; evidence from Nairobi Securities Exchange, Kenya.

The specific objectives of this study are:

i. To establish the relationship between dividend yield anomalies and firms' financial distress; evidence from Nairobi Securities Exchange, Kenya.

ii. To determine the relationship between price to earnings anomalies and firms' financial distress; evidence from Nairobi Securities Exchange, Kenya.

\subsection{Research Hypotheses Testing}

The research will test the following null hypotheses:

$H_{01}$ : Dividend yield anomalies have no significant relationship with the firms' financial distress; evidence from Nairobi Securities Exchange, Kenya. $H_{02}$ : Price to earnings anomalies have no significant relationship with the firms' financial distress; evidence from Nairobi Securities Exchange, Kenya.

\section{Literature Review}

Various studies have thrown their weights behind this noble idea that high dividend yield stock outshines the market in performance than the low dividend yield stocks. Patel, Yao and Barefoot (2006), found out that stocks having high dividend yield and low payout ratio outperform the stocks possessing low dividend yield. It is also evident that the ex-dividend date is normally identified by abnormal returns or earnings on that material date. It was also discovered that there exists a negative and non-significant return on the ex-dividend date. It is also interesting to see that there is existence of a positive and significant return on day before the dividend payment day.

Patel et al., (2006) research showed that stocks that have performed better in respect to the market price usually give out a higher dividend yield than stocks whose performance are lower which usually give out a lower dividend yield. This finding differ with the other findings which advocate that the higher the performance of the financial instruments, then the lower the dividend yields which is an anomaly. In the study of Patel et al., (2006), such investors use an investment strategy commonly known as the "against the market". This means that the investors will purposely select their portfolios in which they will be very keen in securities which are most neglected in the market.

Fama (1991) found out that low price to book (P/B) as the stocks whose ratio generate more returns than the stocks with a high $\mathrm{P} / \mathrm{B}$ ratio. This is an anomaly which is fundamental in nature as it is expected that stocks with a low $\mathrm{P} / \mathrm{B}$ ratio will definitely outperform the low P/B ratio stocks. This is so as under normal 
circumstance, it is expected that stocks with low $\mathrm{P} / \mathrm{B}$ ratio ought to generate low return and not vice-versa. Fama and French (1998) states that stocks with high dividend yield will generate more returns as the market will be outperform by the former. If the yield in dividend is high, then the expectation is that the stock definitely generate more return.

According to the study of Basu (1977), stocks with low price to earnings ratios tend to have higher average returns than the stocks with high price to earnings ratios. $\mathrm{He}$ also indicated that there was a belief that price to earnings ratio is good indicator of the future investment performance of a security. He further went on to say that the proponents of the price to earnings claim that low price to earnings securities will tend to outperform high price to earnings stocks. From this study it was also found that returns on stocks with low price to earnings tend to be larger than warranted. Elena-Dana and Iona-Christina (2013) found out that there subsists positive association between the fundamental anomalies and financial distress in firms. It is due to this anomaly that many firms experience cash crunch or financial distress as they are unable to meet their day to day operational needs of the firm. Goodman and Peavy (1983), document that stocks with low price to earnings (P/E) ratios have higher chances of generating higher earnings and outdo the market. This happens as the stocks with high price to earnings $(\mathrm{P} / \mathrm{E})$ ratios are likely to underperform than the market index, which is a price to earnings anomaly.

Graham and Dodd (2008), there subsists a positive association between the fundamental anomalies and financial distress as the value approaches outdo the market. In the value approaches the stocks with low price respective to earning, historical prices and dividend are buy outs. Malholtra and Tandon (2013), undertook a study which took place in National Stock Exchange (NSE) in New Delhi, India. The researchers found out that the firm's dividend yield had a significant inverse relationship the firm's stock market price.

\subsection{Theories}

A theory is defined as a set of assumptions and propositions. The main reasons why there are theories formulations are to explain, predict and understand phenomena. Theories are to question and enhance existing knowledge within the boundaries of very important hypotheses, (Abend, 2008). In this study, dividends and financial distress theories are applicable as they form an integral part of the study.

\subsubsection{Dividends Theories}

Dividend refers to the fraction of net profits of a firm which is apportioned to the shareholders. A decision on dividend points out to all means used in the determination of the dividend levels that can be distributed to the shareholders. The later raises the concern in deciding between the dividends distribution and the capitalization of a greater part of the net profit of a firm. The dividend decision is the most contentious as the challenging point for both financing and investment 
decisions is the dividend itself, (Lumby, 1991). The dividend mystery has been both an enduring concern in finance and also stands unsettled, (Al-Malkawi, Rafferty \& Pillai, 2010).

Theories of dividend decision are the support and the modelers of practices for decisions in dividends. There are two theoretical trends where there are theories that promote the distribution of dividends and theories that discourage the distribution of dividends, (Berceanu \& Siminica, 2009). Dividends theories comprise of dividend relevance theory, dividend irrelevance theory, residual theory of dividends, the bird-in-hand theory of dividends and the tax preference theory of dividends. All these dividends theories came into being through the works of Professors James E. Walter, Myron Gordon, Modigliani and Miller, (Walter, 1963, Gordon, 1963, Modigliani \& Miller, 1961). The last two researchers are commonly referred to as $\mathrm{MM}$ in the field of finance.

\subsection{Dividend Relevance Theory}

This is when there is preference of the dividend policy that influences the firm's value. With such a dividend policy in place then it means that a change in the dividend payout will definitely lead to a proportionate change in the market value of the firm. There ought to be an optimum dividend payout ratio for a theory to be considered to be relevant. The optimum payout ratio more often than not grants the highest market value per share. The dividends relevance theory is supported by Walter's and Gordon's models, (Walter, 1963 and Gordon, 1963).

In Walter's Model, the optimum dividend policy relies heavily on the association between the firm's internal rate of return and the cost of capital. When the internal rate of return $(r)$, is more than the cost of capital $(k)$, then the firm should retain the whole revenues. Whereas when the internal rate $(r)$ of return is less than the cost of capital $(k)$, this implies that the firm should appropriate the earnings to the shareholders. The rationale behind this is that when the internal rate of return $(r)$, is more than the cost of capital $(k)$, then the firm has the ability of generating more earnings than the shareholders who get their returns from the retained earnings, (Walter, 1963).

The Walter's Model is premised on several assumptions. Firstly, the firm is assumed to finance all its investments through retained earnings. Secondly, the internal rate of return of the firm and its cost of capital are always constant. Thirdly, all earnings are either distributed as dividend or reinvested internally without any delay. Fourthly, beginning earnings and dividends never change. Though different values of earnings per share (EPS) and dividends per share (DPS) may be used in the model but they are assumed to be constant while determining a value. Fifthly, the firm has a very long or infinite life. Sixthly, the present value of an infinite stream of constant. Seventhly, it assumes that the capital market is perfect. Lastly, the present value of the infinite stream of stream gains, (Walter, 1963). 
In the Walter's model, firms in financial distress have an internal rate of return $(r)$ which is less than the cost of capital $(k)$ which is equated in this formula, $r<k$. Firms in financial distress are also referred to as declining firms. These firms generate returns which are less than what shareholders can earn on their investments. It is irrational to retain the firm's earnings. It will be logical to maximize the price of the shares and to distribute entire earnings to the shareholders. In such situations, the optimum dividend payout ratio will be at $100 \%$, (Walter, 1963).

Gordon's Model of the dividend relevance theory states that when the internal rate of return $(r)$ is more than the cost of capital $(k)$, then the dividend payout ratio decreases as the price per share increases. When the internal rate of return $(r)$ is less than the cost of capital $(k)$, the price per share remains unchanged in reaction to the corresponding change in the payout ratio, (Gordon, 1963). Comparing the two models, it comes out that there is no much difference between the two. Thus the Gordon's model's conclusion about the dividend policy is the same as that of Walter's, (Walter, 1963 \& Gordon, 1963).

Gordon's Model is also based on several assumptions. The first, assumption is that the firm is an all equity firm. This gives birth to the second assumption, no debt financing is available as the firm is financed purely on equity. Thirdly, the internal rate of return $(r)$ of the firm is constant. Fourthly, the applicable discount rate $(K)$ of the firm is upheld constant. Fifthly, the firm and its source of earnings are ceaseless. Sixthly, the corporate taxes are non-existence or not applicable. Seventhly, the retention ratio $(b)$, once determined, it remains at that and there is no option of changing it. This simply means that the growth rate $(g)$ remains constant perpetually. Lastly, when the discount rate $(K)$ is greater than the retention ratio $(b)$ and the internal rate of return $(r)$ which equals to the growth rate $(g)$, if this condition is unfulfilled, then one fails to get a meaningful value for share. This assumption is depicted by this formula, $K>b r=g$, (Gordon, 1963).

\subsection{Dividend Irrelevance Theory}

The Modigliani and Miller (MM) dividend irrelevance theory asserts that the firm's dividend policy does not possess any influence at all on value of the firm or its stock price, (Modigliani \& Miller, 1961). It continues to state that when the firm is declaring dividends and payments thereof, these would have slight or no impact on stock price. When dividends do not possess the capability of adding or subtracting any value to a firm's stock price, then this theory holds true. Thus the shareholders will not be troubled by the decision of dividend. There is existence of a general belief that the dividend policy has absolutely no repercussion on the share prices of a firm other than the investment policy which is the one that increases the value of firm. The thing that adds to the wealth of the shareholders, the investment and dividend decisions are irrelevant, is just a residual part of the decision, (Modigliani \& Miller, 1961). 
This theory heavily relies on set of assumptions in which one of them is that there is existence of a perfect financial market. This implies that the shareholders can design their own dividend policy simply by using the free forces of the market, demand and supply. The shareholders can therefore engage themselves in buying or selling of shares in the market as they deem fit. In case the shareholders are in need of liquidity, they can freely and willingly sell shares without incurring any brokerage costs. If there is no need of liquidity then the shareholders will not dispose-off their shares but rather hold on to them. Secondly, the theory has an assumption that there are no existence of brokerage fees or capital gains taxes. Thirdly, there is an assumption that there are no such factors as control of voting preferences and any signalling effects which usually comes in as a result of dividend payments, (Modigliani \& Miller, 1961).

When all the above stipulated assumptions are not considered, relaxed or followed strictly, then dividends do not really count. Thus given these assumptions, Modigliani and Miller concluded that the firm's value is not determined purely on dividends. This is the main reason why dividends policy becomes irrelevant in the determination of the firm's value. Thus according to the irrelevance theory, dividend decisions have no capacity of affecting the value of a firm and this is the reason why it is referred to as irrelevance theory, (Modigliani \& Miller, 1961).

The opponents of the dividend irrelevance theory argue that investors are more interested in stocks which have good performance in dividends and thus dividends are very relevant to the value of the firm as they are highly regarded. This is supported by the assertion that most shareholders are in favour of a reasonable dividend which has a sense of stability. These qualities provide the market with an opportunity to positively respond to the stability or a step-by-step increase of the dividend, (Lintner, 1956). According to Halpern, Weston and Brigham, (1998), shareholders favour dividend payments to capital gains which are expected to be generated from the accrued profits which are more often than not reinvested.

\subsection{Residual Theory of Dividends}

It is one of the theories which is not in favour of the dividends allocation. This reasoning becomes true when the dividends are not in direct association with the firm's profit's level, (Berceanu \& Siminica, 2009). It holds that a firm will only issue dividend from residual earnings. This simply means that the dividend which is paid up by a firm is the residual amount after the firm has undertaken all other investment and financing activities. Residual amount therefore can be said to be the amount that remains after all admissible financing and investment opportunities have been done away with. A residual dividend policy can therefore be looked at as one that is designed not to be paying dividend, but the firm will have to pay a special dividend when only certain conditions are met, (Baker, 2011).

A firm with a residual policy tends to hold zero cash at any given point in time. This is so because all excess cash can either be reinvested in the firm to boost its business operations or be redistributed among the shareholders, (Baker, 2011). However this 
is an assumption based on the perfect stock market, but in reality there are imperfections in the stock market which makes it very unlikely for a firm to strictly pursue a pure residual policy. To be at par with the reality of the stock market, then firms adopt smooth dividend policies that demonstrate some correlations with firm's past and present earnings. This theory ensures that cash is only reinvested into profitable investments. The residual dividend theory is based on the following equation;

Dividends $=$ Net Income $-($ Target Equity Ratio $\mathrm{x}$ Total Capital Budget $)$

Fourthly, the residual theory of dividend emphasizes the thought that earnings that cannot be used in profitable projects should be refunded back to shareholders as dividends. This will then automatically bar the negatives associated with the signalling effects. Fifthly, while firms should not be encouraged to utilize the residual model in setting out the annual dividend payouts, they are inspired to utilize the model in setting up the long-run target of the firm's payout ratio. Lastly, the residual thought can be easily mixed up with one of the various cash adjustment smoothing techniques. In most instances, this is the way it is applied in real-world dividend practice, (Smith, 2009).

The proponents of the residual dividends theory argue that a firm may make use of the dividend as a signaling mechanism for investors and other stakeholders. It portrays the firm's growth potentiality and stability. Furthermore, dividend forms a sizable chunk in a firm's capital structure (Frank \& Goyal, 2003; Aggarwal \& Kyaw, 2010). When this happens, the proponents of the residual dividend theory contends that if there is no profitable business opportunities, then firms can only disburse profit, (Baker \& Smith, 2006; Smith, 2009).

As much as there are proponents of this theory, there are also opponents of the same. The opponents of the residual dividend theory states that this theory is complicated, thus firms often favour dividend model which has the elements of continuity and stability to a pure residual policy, (Smith, 2009). This two elements are very important in the determination of the preferred if not favoured model to be adopted. Other opponents state that due to the association between dividends and the investment needs of firms, it renders the dividends unstable and thus the investors might have a view that this theory is unreliable, (Baker, 2011).

\subsection{The Bird-in-the-Hand Theory of Dividends}

It is a theory that was deliberated by Gordon and Lintner also known as Gordon/Lintner Theory, (Gordon, 1963 and Lintner, 1962). It states that due to the uncertainties which surround the capital gains, investors prefer stock dividends which they are sure of rather than potential capital gains which they are not sure of. This means that there is certainty to the dividends which is of today, while there exist a lot of uncertainty to the capital gains of tomorrow. It was developed to counter the Modigliani-Miller (MM) dividend irrelevance theory in which the investors are indifferent betwixt dividends today and capital gains tomorrow, 
(Modigliani \& Miller, 1961). The MM dividend irrelevance theory preserves that investors are not bothered with where their returns come from. There exists studies which stand up as the major proponents of the bird-in-the-hand theory, (Gordon \& Shapiro, 1956; Gordon, 1959 \& 1963; Lintner, 1962 and Walter, 1963).

The theory takes a fundamentally about turn view of dividends from what had been initially brought to the attention of the researches and scholars. Myron Gordon came up with the model which detailed the association between the stock's price and the dividend which came to be commonly known as the Gordon Growth Model (GGM) or the Dividend Discount Model (DDM), (Gordon, 1963). The very noble thinking behind the curtain of this theory by Gordon and Lintner was that low dividend payout catapults into increase in the cost of capital. Thus the more the dividend payout rate, the more the stock price.

This model is expressed as:

Stock Price $=\frac{D_{0} X(1+g)}{k_{e}-g}=\frac{D_{1}}{k_{e}-g}$

Where $D_{0}$ is the per share amount of last dividend paid, $g$ is constant growth rate, $k_{e}$ is investors' requisite rate of return and $D_{1}$ is the expected dividend.

This theory sticks to the idea that investors or shareholders are not indifferent between dividends today and a proportionate amount of capital gains at a later date. In other words, it states that investors favour stock dividends today to potential capital gains tomorrow due to uncertainty of the capital gains. It should be understood that investors prefer a surer dividend today to a more uncertain capital gain tomorrow. Investors count on something they have put in their pockets today to hopes of tomorrow, (Gordon, 1963 and Lintner, 1962).

The theory asserts that investors under normal circumstances discount the expected capital gain yield at a much higher rate than the dividend yield. This means that firms which employ a high dividend pay-out coincidentally have also a low expected yield in capital gain. They can afford to pay shareholders who under normal circumstance favour a high current pay-out at a lower total rate of return than firms which employ a lower dividend pay-out strategy. When a desired lower return results is to be achieved then a higher stock price would be put for firms. This is done so with the sole aim of the stock prices matching the high current pay-out pattern which is the main desire of the bird-in-the-hand investors, (Frankfurter \& Bob, 2002).

According to Gordon and Lintner, the bird-in-the-hand theory relied on the following assumptions. Firstly, the company is financed by only equity, thus no debt finance is used. Secondly, retained earnings is the only source of finance which means that no other sources of financing is available. Thirdly, there is a constant retention ratio which indicates that there is a constant growth rate of earnings. Fourthly, the firm's cost of capital is constant and is always greater than growth rate. Lastly, there is no existence of corporate tax, (Gordon, 1963 \& Lintner, 1962). 
The main proponent of this theory of the bird-in-the-hand were MM, who had advanced an argument that the dividend policy had absolutely no bearing at all on the cost of capital of a firm and that shareholders are only concerned with the in total returns (Modigliani \& Miller, 1961). This means that dividends are not relevant to the share of capital gains and dividends. This further means that investors or shareholders more often than not reinvest dividend by buying more stocks of the same or other different firms. This indicates that firms plough back the biggest share of dividends payouts. This brings in a conclusion according to Modigliani-Miller (MM), that this theory is irrelevant simply because the firm's value or cost of capital is not relevant to the bird-in-the-hand theory as it depends on its capability to generate earnings and lower the business risk.

\subsection{Tax Preference Theory of Dividends}

The tax preference theory asserts that a few investors look up to long-term capital gains to current dividend yield. Investors look favourably at firms which consider paying low dividends or not paying any dividends at all as the taxes to be paid if any are very minimal. These shareholders are more than willing to pay extra for the stock of a firm that has the capability of recouping its earnings into capitalappreciating investments rather than disbursing these revenues as dividends. In a capital market of perfection, there is no any taxes, transaction costs or agency cost, (Modigliani \& Miller, 1961).

The time value of money and taxes form basis of the tax preference theory. This is considered so, since to the tax man, the stock price appreciation attracts less tax compared to the kind of taxes that are levied to the dividend pay-outs. Shareholders of a firm would be more comfortable in choosing for the after-tax return instead of paying tax on dividends which causes the dividends and capital gains to exist with differential in tax treatment. It also demonstrates that when cut down, the dividend pay-out ratio can determine the firm's value in reaching the maximum point and add on with that cost of capital which will definitely also decrease, yet the stock price will immediately increase, (Laiboni, 2013).

According to Shackelford (2001), tax occupies a central role in the determination of stock prices. It was also noted that there is a response of stock prices which are respond spontaneous to the changes in the capital gains tax policy. It is worth noting and also of great importance that the stock prices respond instantaneously to information on tax legislation, (Fama et al., 1969). Lastly the price of stock response is widely complete by public broadcast of the change of the tax policy, (Fama et al., 1969). Thus the significance of the price of stock response is material, (Shackelford, 2001).

There exist underlying assumptions of tax preference theory which are to be met for the theory to hold and they and they are enumerated as follows. Firstly, the capital gains tax rate is assumed to be of higher rate or the same to the dividend tax rate. If this assumption holds then the investors will in favour buying of stocks of firms which in practice or in normal operation do not pay any dividends. This will assist them maximizing on their cash flows, (Modigliani \& Miller, 1961). 
Secondly, it is assumed that the capital gains tax has to be paid at that time when there is actual realization of the capital gains. Investors have the capacity of deciding when capital gains will be realized, that is, when they actually feel to offload their stock. In contrast, dividend payouts solely rely on the firms' management which infers that the investors do not have the ability of influencing it in any way. Lastly, if an investor passes on, then the heirs will not be in a position of paying capital gains tax. This is so as the heirs may opt to sell the inherited stock and thus avoid paying the capital gains tax, (Modigliani \& Miller, 1961).

\subsubsection{Financial Distress Models}

These are models which are applied in foretelling the status of financial health of different firms. Financial distress models comprise of Traditional Ratio Analysis (TRA), Z-Score, ZETA and Wreckers Theory of Financial Distress. Amongst the measures applied, Z-Score was found to be the most preferred measure of financial distress as it was $80-90 \%$ in the determination of the financial distress levels in firms, (Altman, 2000). Thus with such a high level of accuracy, the Z-sore will be used in this study as the measurement tool of the financial soundness or health of firms listed in Nairobi Securities Exchange.

\subsection{Z-Score Model}

Limitations which were witnessed in the Traditional Ratio Analysis (TRA) saw the birth of Z-Score model. It came into being in 1968 through the works of Edward I. Altman and was regarded as quantitative balance sheet technique of dictating a firm's financial health. Altman puts into use a technique of multiple discriminant analysis (MDA). This method was basically invented to sort out the vagueness dilemma connected with Beaver's univariate examinations and to assess a wholesome firm's financial profiling, (Wang, Wang \& Wang, 2017).

The original work was premised on the data sourced from 66 publicly held manufacturers. It was surprising to note that a half of firms had filed for bankruptcy during the period of 1946-1965. Altman examined 22 potentially helpful financial ratios out of which he picked five that when combined provided the best overall prediction of corporate bankruptcy. The variables which Altman used were classified into categories of five standard ratio as: liquidity, leverage, profitability, market value and efficiency ratios, (Altman, 1968). Below is the model which was applicable for the manufacturing firms;

$Z-$ Score $=1.2 X_{1}+1.4 X_{2}+3.3 X_{3}+0.6 X_{4}+0.999 X_{5}$

Where $\mathrm{X}_{1}=$ Working Capital/Total Assets (Liquidity)

$\mathrm{X}_{2}=$ Retained Earnings/Total Assets (Leverage)

$\mathrm{X}_{3}=\mathrm{EBIT} /$ Total Assets (Profitability)

$\mathrm{X}_{4}=$ Market Value of Equity/Total Liabilities (Market Value)

$\mathrm{X}_{5}=$ Sales/Total Assets (Efficiency) 
According to Altman, Hartzell and Peck (1995), for non-manufacturing firms, the model does not have the sales/total assets ratio as this was to minimize the risk in the potential industry. The model specifications are as follows;

$Z-$ Score $=6.56 X_{1}+3.26 X_{2}+6.72 X_{3}+1.05 X_{4}$

When the Z-Score is above 2.99, the firms are viewed to be in "safe" zone. When the score is between 1.81 and 2.99, is a "gray" zone as there is a likelihood of the firm getting into financial difficulty in the next 2 years of operation. If the Z-Score is below1.81, then a firm is considered to be in a "distress" zone in which there is a high probability of financial distress within the time period, (Altman, 2000).

\subsection{Conceptual Framework}

Myers (2013), states that conceptual framework uses graphs or diagrams in representing associations among variables being investigated by the research. Kothari and Garg (2014), show that if one variable is dependent on another or is the result of that variable, then we have a dependent variable. The predecessor variable to the dependent variable is called an independent variable. This shows that an independent variable is a phenomenon that is manipulated to determine the value of a dependent variable. Independent variable may also mean a variable whose variation does not depend on that of another variable.

Independent Variable

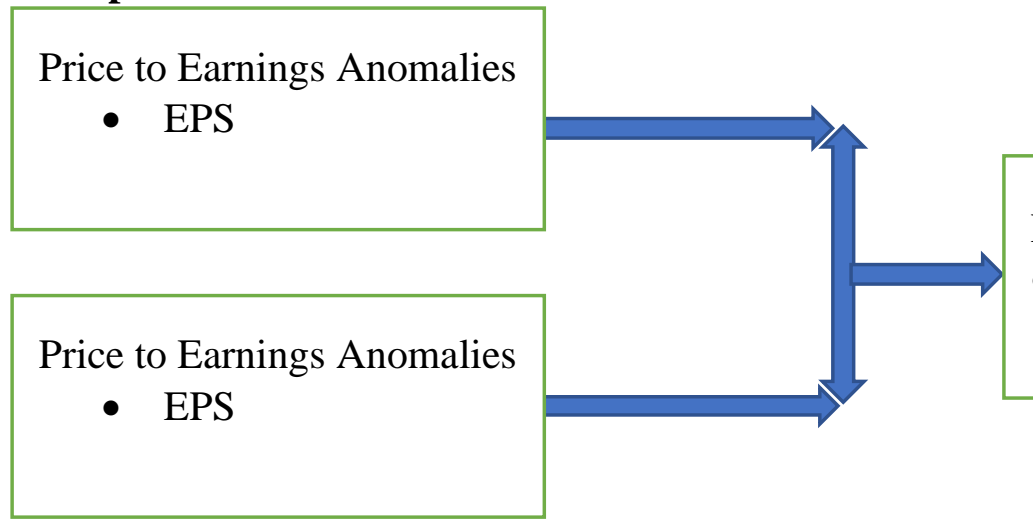

Dependent Variable

Financial Distress

- Z-Score

Figure 1: Conceptual Framework 


\section{Research Methodology}

Dawson (2014) categorically points out that research methodology is the general principle that gives direction to the research. Kombo and Tromp (2013) also acknowledge that research methodology concentrates on the demonstration of the techniques used in conducting the study. It comprises of research design, population of the study, scope of the study and sources of data.

\subsection{Research Design}

Is a universal scheme of acquiring responses to the questions being researched and administering the complications experienced in the course of the research, (Polit \& Beck, 2017). This study adopts the descriptive research design. Grove, Burns and Gray (2014), assert that a descriptive research design is planned to take the picture as it is basis or the way it naturally occurs. Cooper and Schindler (2014), put it in a clearer way by stating that descriptive research enables an in depth study of phenomena or characteristic associated with the subject population such as to who, what, when, where and how of the subject.

\subsection{Population of the Study}

Population is portrayed as the entire cluster of elements that conclusions ought to be drawn, (Cooper \& Schindler, 2014). In this study, census will be considered as all firms in the population target will be considered for analysis. It is favoured because of the definite number of elements in the target population that made it practicable to research each and every listed firm. According to Kothari and Garg (2014), census methods involves an exhaustive enumeration of the units constituting the target population. Therefore all the firms, 67 in total which were listed in Nairobi Securities Exchange and licensed by Capital Market Authority by $1^{\text {st }}$ January, 2017 were considered.

\subsection{Scope of Study}

The study covers a period of 11 years from $1^{\text {st }}$ January 2007 to $31^{\text {st }}$ December 2017.

\subsection{Sources of Data}

This study relies heavily on the quantitative and secondary data collection methods. In secondary data collection, a researcher simply relies on the works of another to get on moving with their intended study. Kothari and Garg (2014), secondary data must be suitable, adequate and reliable. The study used panel data technique for the 11 year period, $1^{\text {st }}$ January, 2007 to $31^{\text {st }}$ December, 2017, to examine the relationship between fundamental anomalies and financial distress of listed firms in the Nairobi Securities Exchange. Regression coefficients were made clear by the application of the E-views software output. Annual data encompassing the entire period of study were considered as this was to ensure that there was enough degrees of freedom estimations in the models. The secondary data was acquired from published annual financial reports of all firms in the Nairobi Securities Exchange. 
Also relevant literature in magazines, websites and other relevant secondary sources formed part of secondary data.

\section{Main Results}

The main results of this study were relayed by the use of descriptive statistics, correlation analysis, unit root tests and panel regression equation. The interpretation of the regression coefficients were modeled by the utilization of the E-views software output.

\subsection{Descriptive Statistics}

Descriptive statistic is a summary statistic that describes quantitatively the features of data. Descriptive statistics are utilized in the presentation of the quantitative descriptions in a form that can be managed easily, (Williams, 2006). This study therefore seeks to determine the spread of data that comprise of the calculations of the mean, standard deviation, standard errors, maximum and minimum values of the variables overtime. This further involved finding the correlation matrix in order to ascertain variables which were highly correlated as this would assist in avoiding the issue of multicollinearity which is common occurrence in time series data.

In this study, the data was changed into their natural logs so as to deal away with the challenges of these large numbers as this will also to see the elimination of heteroscedasticity. It also considered correlation analysis as a mean of checking the variables which are highly correlated with the sole aim of reducing the problem of multicollinearity which is very common face in time series data. It further involved the normality tests which are in the form of skewness, kurtosis and Jarque-Bera, (Jarque \& Bera, 1987). 
Table 1: Descriptive Statistics

\begin{tabular}{|l|c|c|c|}
\hline & LN_Z & LN_FAD & LN_FAE \\
\hline Mean & 0.919192 & -3.270962 & -2.378667 \\
\hline Median & 0.917689 & -3.316346 & -2.378968 \\
\hline Maximum & 1.942604 & 1.806648 & 1.557335 \\
\hline Minimum & -0.580257 & -10.01002 & -5.791751 \\
\hline Std. Dev. & 0.574154 & 1.198330 & 0.959136 \\
\hline Skewness & -0.030158 & -0.886188 & 0.125238 \\
\hline Kurtosis & 2.264766 & 12.46913 & 5.164125 \\
\hline Jarque-Bera & 2.947791 & 502.6981 & 25.70844 \\
\hline Probability & 0.229032 & 0.000000 & 0.000003 \\
\hline Sum & 119.4950 & -425.2251 & -309.2268 \\
\hline Sum Sq. Dev. & 42.52527 & 185.2432 & 118.6724 \\
\hline Observations & 130 & 130 & 130 \\
\hline
\end{tabular}

\section{Notations:}

LN_- Natural log of

LN_Z - Natural log of Z-Score

LN_FAD - Natural log of Dividend Yield Anomalies - Dividend per Share

LN_FAE - Natural Log of Price to Earnings Anomalies - Earnings per Share

\subsubsection{Financial distress}

Financial distress is measured through equations (3) and (4) which result into Zscore, (Altman, 2000). Out of the 67 listed firms in NSE, financial distress which is the dependent variable had a skewness value of -0.0302 which meant that it was negatively skewed and thus the curve was not normally distributed as the value was not zero. The kurtosis value was 2.2648 signified that the curve was mesokurtic as this value was less than three and thus not normal. A Jacque-Bera value of 2.9478 meant that this curve was not normally distributed as the value was not close to zero.

\subsubsection{Dividend Yield and Price to Earnings Anomalies}

The dividend yield anomaly which is measured by the Dividends Per Share (DPS) and is connoted by FAD, had a skewness value of -0.8862 . Since this value is not zero and is below zero, then the FAD is negatively skewed and thus not normal. Kurtosis value of 12.4691 means that the curve is not normal but kleptokurtic as this value is more than three. Jarque-Bera of 502.6981 as per Table 1 meant that this curve is not normal as the value is not close to zero.

The price to earnings anomalies which is measured by the Earnings Per Share (EPS) and is connoted by FAE, had a skewness of 0.1253 . This indicated that the curve is not normal as the value is not zero and further indicated that the curve is positively skewed. Kurtosis value of 5.1641, meant that this curve was kleptokurtic as the value was more than three, thus not normal. Jarque-Bera of 25.7084, meant that the value is not close to zero, thus this is not a normally distributed curve. Thus, in 
normality tests, the results showed that the data for both FAD and FAE under consideration were not normal.

\subsection{Correlation Analysis}

Table 2: Correlation Analysis

\begin{tabular}{|l|c|c|c|}
\hline & LN_Z & LN_FAD & LN_FAE \\
\hline LN_Z & 1.000000 & & \\
\hline LN_FAD & 0.329061 & 1.000000 & \\
\hline LN_FAE & 0.062851 & 0.339948 & 1.000000 \\
\hline
\end{tabular}

In Table 2, the dividend yield anomaly had a correlation coefficient value of 0.3291 with the Z-score, signifying a moderate positive correlation with the Z-sore. This is so as the correlation value was between 0.2 and 0.4 . This means that when the independent variable, dividend yield anomaly is increased by 0.3291 per year then the dependent variable, financial distress is increased by one percent in the subsequent year. Price to earnings anomaly had a coefficient value of 0.0629 signifying a weak positive correlation with the Z-score as the correlation value was below 0.2. This means that when the independent variable, price to earnings anomaly, is increased by 0.0629 per year then the dependent variable, financial distress is increased by one percent in the subsequent year.

\subsection{Unit Root Tests at Intercept and Level I (0)}

In the panel unit root test framework, various tests have been developed. These tests are; Levin, Lin and Chu, Im, Pesaran and Shin, Augmented Dickey-Fuller, Plackett and Pearson and fisher type tests, (Levin et al., 2002; Im et al., 2003; Dickey \& Fuller, 1981; Plackett \& Pearson, 1983). The main limitation of these tests based on the assumption of cross-sectional independence across variables. In this section, the study critically analyses the dependent variable, financial distress and the independent variables which include dividend yield and price to earnings anomalies independently with their measures in determination whether the variables possess the unit root or not.

\subsubsection{Financial Distress}

Financial distress was found to be stationary at intercept and level I (0) because the Levin, Lin and Chu, Im, Pesaran and Shin, Augmented Dickey-Fuller, Plackett and Pearson had probability values of 0.0000 which were significant at one percent level of significance. Therefore, we fail to accept the null hypothesis that dependent variable, financial distress has a unit root. 
Table 3: Panel Root Test for FD

\begin{tabular}{|l|c|c|c|c|}
\hline \multicolumn{5}{|c|}{$\begin{array}{c}\text { Panel unit root test: Summary } \\
\text { Series: LN_Z }\end{array}$} \\
\hline Method & Statistic & Prob. & Cross-sections & Obs \\
\hline Null: Unit root (assumes common unit root process) \\
\hline Levin, Lin \& Chu & -23.2433 & 0.0000 & 48 & 446 \\
\hline \multicolumn{2}{|c|}{ Null: Unit root (assumes individual unit root process) } \\
\hline Im, Pesaran and Shin W-stat & -5.75092 & 0.0000 & 48 & 446 \\
\hline ADF - Fisher Chi-square & 170.348 & 0.0000 & 48 & 446 \\
\hline PP - Fisher Chi-square & 188.212 & 0.0000 & 48 & 454 \\
\hline
\end{tabular}

\subsubsection{Dividend Yield Anomaly}

Was found to be stationary at intercept and level I (0) as the Levin, Lin and Chu; Im, Pesaran and Shin; Augmented Dickey-Fuller; Plackett and Pearson for dividend yield anomaly (FAD) had probability values of 0.0000 which is significant at one percent level of significance. Therefore, we fail to accept the null hypothesis that dividend yield anomaly (FAD) has unit roots.

Table 4: Panel Root Test for FAD

\begin{tabular}{|l|c|c|c|c|}
\hline \multicolumn{5}{|c|}{$\begin{array}{c}\text { Panel unit root test: Summary } \\
\text { Series: }\end{array}$ LN_FAD } \\
\hline Method & Statistic & Prob. & Cross-sections & Obs \\
\hline Null: Unit root (assumes common unit root process) \\
\hline Levin, Lin \& Chu & -14.0202 & 0.0000 & 41 & 344 \\
\hline \multicolumn{2}{|c|}{ Null: Unit root (assumes individual unit root process) } \\
\hline Im, Pesaran and Shin & -6.39159 & 0.0000 & 40 & 341 \\
\hline ADF - Fisher Chi-square & 182.521 & 0.0000 & 41 & 344 \\
\hline PP - Fisher Chi-square & 215.812 & 0.0000 & 41 & 349 \\
\hline
\end{tabular}

\subsubsection{Price to Earnings Anomaly}

Price to earnings anomaly (FAE) was found to be stationary at intercept and level I (0) because the Levin, Lin and Chu, Im, Pesaran and Shin, Augmented DickeyFuller, Plackett and Pearson had probability values of 0.0000 which is significant at one percent level of significance. Therefore, we fail to accept the null hypothesis that price to earnings anomaly (FAE) has unit roots. 
Table 5: Panel Root Test for FAE

\begin{tabular}{|l|c|c|c|c|}
\hline \multicolumn{5}{|c|}{$\begin{array}{c}\text { Panel unit root test: Summary } \\
\text { Series: }\end{array}$ LN_FAE } \\
\hline Method & Statistic & Prob. & Cross-sections & Obs \\
\hline \multicolumn{4}{|c|}{ Null: Unit root (assumes common unit root process) } \\
\hline Levin, Lin \& Chu & -15.8765 & 0.0000 & 47 & 373 \\
\hline Null: Unit root (assumes individual unit root process) \\
\hline Im, Pesaran and Shin & -5.66762 & 0.0000 & 45 & 367 \\
\hline ADF - Fisher Chi-square & 182.055 & 0.0000 & 47 & 373 \\
\hline PP - Fisher Chi-square & 199.274 & 0.0000 & 47 & 379 \\
\hline
\end{tabular}

\subsection{Panel Regression Equation}

The data was lagged by one period since fundamental anomalies experienced in one period tend to have their implications felt in the subsequent periods. In panel regression equation there is the use of Hausman test, which was applicable to all the variables under consideration, (Hausman, 1978). In Hausman test, Chi-square test statistic was considered in determination of the level of significance. This led to decision making on whether to adopt the fixed effects model or random effects model.

$\gamma_{i t}=\beta_{0}+\beta_{1} X_{1 i t}+\beta_{2} X_{2 i t}+\epsilon_{i t}$

Where $X$ is the independent variables, $X_{1}$ is dividend yield anomaly, $X_{2}$ is price to earnings anomaly, $\gamma_{i t}$ is the dependent variable denoting financial distress of firm $\mathrm{i}$ at time $\mathrm{t}, X_{i t}$ is the independent variable of firm $\mathrm{i}$ at time $\mathrm{t}, \beta_{0}$ is the constant term, $\beta_{i}$ is the coefficient of the independent variables.

\subsubsection{Hausman Test}

Table 6 was used in determination of the most suitable model to be used in this study which is choosing between fixed effects model and random effects model. The Chi-square test statistic was 18.4369 with a significant probability value of 0.0052 which was significant at one percent level of significance. When the probability value is more than 0.05 we accept the use of random effects model and when the value is less than 0.05 then this allows the applicability of the fixed model. Table 6 gave a probability value is 0.0052 which is less than 0.05 and thus the adoption of the fixed effects model. 
Table 6: Correlated Random Effects - Hausman Test

\begin{tabular}{|c|c|c|c|c|}
\hline \multicolumn{5}{|c|}{ Correlated Random Effects - Hausman Test } \\
\hline \multicolumn{5}{|c|}{$\begin{array}{l}\text { Equation: EQ02FIRSTDIFFERENCE } \\
\text { Test cross-section random effects }\end{array}$} \\
\hline Test Summary & & Chi-Sq. Statistic & Chi-Sq. d.f. & Prob. \\
\hline Cross-section & & 18.436861 & 6 & 0.0052 \\
\hline \multicolumn{5}{|c|}{ Cross-section random effects test comparisons } \\
\hline Variable & Fixed & Random & Var(Diff.) & Prob. \\
\hline DFAD & 0.379601 & 0.279855 & 0.000950 & 0.0012 \\
\hline DFAE & -0.249160 & -0.069527 & 0.004241 & 0.0058 \\
\hline
\end{tabular}

\section{Notations:}

D - First Difference of

DFAD - First Difference of Dividend Yield Anomaly

DFAE - First Difference of Price to Earnings Anomaly

DZ - First Difference of Z-Score

\subsubsection{Fixed Effects Model}

This is analyzed in all the independent variables with their measures being taken into consideration as per Table 7 .

Table 7: Fixed Effects Model

\begin{tabular}{|c|c|c|c|c|}
\hline \multicolumn{5}{|c|}{$\begin{array}{c}\text { Dependent Variable: FD } \\
\text { Method: Panel Least Squares }\end{array}$} \\
\hline Variable & Coefficient & Std. Error & t-Statistic & Prob. \\
\hline DFAD & 0.379601 & 0.068816 & 5.516165 & 0.0006 \\
\hline DFAE & -0.249160 & 0.090862 & -2.742164 & 0.0254 \\
\hline C & -0.010649 & 0.018645 & -0.571121 & 0.5836 \\
\hline \multicolumn{5}{|c|}{ Effects Specification } \\
\hline Cross-section fixed (dummy variables) \\
\hline R-squared & 0.964596 & Mean dependent var & -0.005585 \\
\hline Adjusted R-squared & 0.845108 & S.D. dependent var & 0.203078 \\
\hline S.E. of regression & 0.079924 & Akaike info criterion & -2.164000 \\
\hline Sum squared resid & 0.051103 & Schwarz criterion & -0.932374 \\
\hline Log likelihood & 66.95200 & Hannan-Quinn criter. & -1.734130 \\
\hline F-statistic & 8.072745 & Durbin-Watson stat & 3.492419 \\
\hline Prob (F-statistic) & 0.002294 & \\
\hline
\end{tabular}

R-squared is at 0.9646 , signifying that $96 \%$ of fundamental anomalies are explained by financial distress which leaves only $4 \%$ to be explained by other variables. The adjusted R-squared has a value of 0.8451 which depicts that $85 \%$ of the fundamental anomalies can be explained by financial distress. Also it is note that the difference 
between the R-squared and adjusted R-square is $11 \%$ which is less than $20 \%$ meaning that the fixed effect model is very stable.

\section{Findings}

The dividend yield and price to earnings anomalies data are not normally distributed indicating that there exists outliers. Being an outlier means that an individual differs from other members of a particular group or set. This further means that there exist some values which are either extremely high or extremely low. This finding supports the existence of the dividend yield and price to earnings anomalies in this study as they do not conform to the norm or their end game and give completely unexpected results.

This study examined and found out that there was a moderate positive and significant relationship dividend yield anomalies and firms' financial distress. It was found that the significance was at one percent level of significance. This signified that a slight change in dividend yield anomaly conversely causes a similar change in the financial distress of a firm. This is very critical in determination of the financial health of a firm as a slight change in one variable has a ripple effect on the other variable. Therefore this study established that there was indeed an evidence of the relationship between dividend yield anomalies and firms' financial distress on Nairobi Securities Exchange, Kenya.

In the outcome of the Hausman Test, the Fixed Effect Model was preferred to the Random Effects Model as the result value was 0.0052 which is less than 0.05 . The fixed effects model which was as a result of the Hausman Test, was found also to be stable as the difference between the R-squared and adjusted R-squared was less than $20 \%$, in fact actually at $11 \%$.

\section{Conclusion}

In the results of both measures, dividends per share and earnings per share, we conclude that since we failed to accept the null hypotheses, $H_{01}$ and $H_{02}$, thus we have examined that indeed there is evidence of a significant relationship between fundamental anomalies and firms' financial distress in the Kenyan stock market. This conclusion agrees with the findings of Elena-Dana and Iona-Christina, (2013), Graham and Dodd, (2008). This therefore signifies that fundamental anomalies has got a direct impact on the financial health of firms listed in the Nairobi Securities Exchange and as such when the annual financial statements and reports are released, the stakeholders need to be keen in the information on dividends and earnings per share.

This conclusion signifies that fundamental anomalies have a direct link with financial distress as firms in financial distress have very low or do not declare dividends or earnings per share. This confirms the the bird-in-the-hand theory of dividends which shows the existence of a positive relationship between the stock's price and the dividend, (Gordon, 1963). The investors who have put their investments in the stock market will be keen on the financial health of the firms 
listed in the Nairobi Securities Exchange as much as they will get capital gains but also will gain or acquire more wealth in terms of dividends payments.

\section{Recommendations}

The results demonstrated that dividends have great impact on all the shareholders of a firm. The management should therefore put in place the right dividend policies to guide the firm on the treatment of dividends declaration or non-declaration at the end of the financial period of the firm. The dividends declaration or non-declaration is the sole prerogative of the management and as such it should be handled well with full information on the impact of the same. As much as dividends show openly how it affects the shareholders of firms, likewise are the earnings per share which makes the stakeholders of firms to make management or financial decisions. This also calls for the management to be vigilant in the firm's earnings per share as it will eventually determine the financial health of a firm.

Before making an investment decision, the investors need to engage experts who will be mandated to carry out due diligence on the listed firms before investing in them. As the study has pointed out that firms which are about to experience can be predicted in two years before this happens, then potential investors should be wary and not invest in such stocks. If they do, then definitely in two years to come, they will lose their wealth. Investors should invest in financially healthy firms.

The policy makers and regulators should get rid of malpractices such as giving cooked and untimely annual financial reports of the listed firms in the Nairobi Securities Exchange. This occurs when the management of a firm intentionally misstate the financial statements and reports to favorably represent the firm's financial performance. It is also known as financial statements manipulation which is usually perpetuated by upper management.

The policy makers and regulators should also make sure that firms in the Nairobi Securities Exchange publish their financial statements and reports in a specific time period and in a prescribed manner. The firms which participate in the Nairobi Securities Exchange are expected to publish their end of year financial statements and reports within a stipulated time frame and to appear in the any of the three most circulated dailies in Kenya. This will get rid of the issues of biasness, errors and unbalanced data panels encountered in the financial statements and reports.

Regulatory bodies such as Capital Market Authority, Central Bank of Kenya and Nairobi Securities Exchange should put up controls so that the firms listed in the Nairobi Securities Exchange give true and fair view of dividends and earnings per share in their end year financials and reports. This will curtail firms which use orthodox means of giving falsified information about their financial position. This will go a long way in helping the potential and existing investors in making the right financial decision in the stock market with all available facts, Fama (1965). 


\section{ACKNOWLEDGEMENTS.}

The success and completion of this paper is indebted to both my supervisors, Dr. Olweny Tobias and Dr. Nasieku Tabitha. I also appreciate all the lecturers of Jomo Kenyatta University of Agriculture and Technology especially the CBD Campus, who willingly and with utmost good faith bestowed their knowledge throughout my study. 


\section{References}

[1] Olweny, T.O. and Kimani, D. (2011). Stock Market Performance and Economic Growth: Empirical Evidence from Kenya Using Causality Test Approach. Advances in Management \& Applied Economics, Vol. 1 (3), pp 153-196.

[2] Alile, Hayford (1984). The Nigerian Stock Exchange: Historical Perspective, Operations and Contributions to Economic Development, Central Bank of Nigeria Bullion, Silver Jubilee Edition, Vol. 2, pp. 65-69.

[3] Bloomfield, Robert (2010). Traditional Vs. Behavioral Finance. Johnson School Research Paper Series, Vol. 22, pp 4.

[4] Santos, Ana C. (2011). Behavioural and Experimental Economics: Are They Really Transforming Economics? Cambridge Journal of Economics, Vol. 35 (4), pp. 706-707.

[5] Karz, G. (2010). Historical Stock Market Anomalies. "Online" $\mathrm{http} / / / \mathrm{www}$.investorhome.com/anomaly.htm (accessed January 2012).

[6] Adeyemi, B. (2011). Bank Failure in Nigeria: A Consequence of Capital Inadequacy, Lack of Transparency and Non-Performing Loans. Banks and Bank System, Vol. 6(1), pp. 99-109.

[7] Wruck, K. (1990). Financial Distress, Reorganization, and Organizational Efficiency: Journal of Financial Economics, Vol. 27, pp. 419-444.

[8] Baimwera, B. and Muriuki, A. M. (2014). Analysis of Corporate Financial Distress Determinants: A survey of Non-Financial Firms Listed in the NSE. International Journal of Current Business and Social Sciences, Vol. 1 (2), pp $58-80$.

[9] Altman, E.I. and Hotchkiss, E. (2010). Corporate Financial Distress and Bankruptcy: Predict and Avoid Bankruptcy, Analyze and Invest in Distressed Debt, Vol. 289. John Wiley \& Sons.

[10] Avramov, Doron, Chordia, Tarun, Jostova, Gergana, and Philipov Alexander (2013); Anomalies and Finanacial Distress: Journal of Financial Economics, Vol. 108 pp. 139-159.

[11] Arnold, Glen (2016). Corporate Financial Management. $5^{\text {th }}$ Edition. Harlow: Pearson Education Limited.

[12] Maina F. G. and Sakwa M. M. (2012): Understanding Financial Distress among Listed Firms in Nairobi Stock Exchange: A Quantitative Approach Using the Z-Score Multi-Discriminant Financial Analysis Model; JKUAT, Nairobi, Kenya.

[13] CMA (2014). Capital Markets and Securities Public Offers Listings and Amendment Regulations.

[14] Elena-Dana, Bako and Ioana-Christina, Sechel (2013). Technical and Fundamental Anomalies. Paradoxes of Modern Stock Exchange Markets; Babeș-Bolyai University, Faculty of Economics and Business Administration, Cluj-Napoca, Romania. 
[15] Patel, P. N., Yao, S., and Barefoot, H. (2006). High Yield, Low Payout. Raport al Credit Suisse.

[16] Fama, E.F. (1991). Efficient Capital Market II: The Journal of Finance, Vol 46(5), pp 1575-1643.

[17] Fama, E.K. and French K.R. (1998). Dividends Yields and Expected Stock Returns. Journal of Financial Economics, Vol. 22(1), pp. 3-25.

[18] Basu, S. (1977). Investment Performance of Common Stocks in Relation to Their Price-Earnings Ratios: A Test of the Efficient Market Hypothesis. The Journal of Finance, Vol. 32(3), pp. 663-682.

[19] Goodman, D. A. and Peavy J. W. (1983). "Industry Relative Price-Earnings Ratios as Indicators of Investment Returns." Financial Analysts Journal, Vol 39(4), pp. 60-66.

[20] Graham, Benjamin and Dodd, David L. (2008). Security Analysis. Principles and Technique, (6 ${ }^{\text {th }}$ Ed.). McGraw-Hill.

[21] Malholtra, Nidhi and Tandon, Kamini (2013). Determinants of Stock Prices: Empirical Evidence from NSE 100 Companies. International Journal of Research in Management and Technology, Vol. 3 (3), pp. 89-95.

[22] Abend, Gabriel. (2008). "The Meaning of Theory." Sociological Theory, Vol. 26, pp. 173-199.

[23] Lumby, S. (1991). Investment Appraisal and Financing Decision. A first Course in Financial Management, Fourth Edition, pp. 470, Chapman \& Hall, London.

[24] Al-Malkawi, H. N., Rafferty, M. and Pillai, R. (2010). Dividend Policy: A Review of Theories and Empirical Evidence. International Bulletin of Business Administration: 1451-243X Issue 9.

[25] Berceanu, D. and Siminica, M. (2009). The Main Theories of the Dividend Decision, Vol. 9.

[26] Walter, James E. (1963). Dividend Policy: Its influence on the Value of Enterprise, Journal of Finance, Vol. 18, pp. 280-291.

[27] Gordon, M.J. (1963). Optimal Investment and Financing Policy, Journal of Fianance, Vol. 18, pp. 264-272.

[28] Gordon, Myron J. (1959). Dividends, Earnings and Stock Prices, Review of Economics and Statistics, Vol. 41, pp. 99-105.

[29] Modigliani, F. and Miller, M. (1961). "Dividend Policy, Growth and the Valuation of Shares." Journal of Business, pp. 411-433.

[30] Halpern, P., Weston, J.F. and Brigham, E. (1998). Management Finances, Economic Editure, Bucharest. pp. 678.

[31] Lintner, John (1956). Distributions of Incomes of Corporations Among Dividends, Retained Earnings and Taxes, American Economic Review, Vol. 46, pp. 97-113.

[32] Baker, H. Kent, (2011). Dividends and Dividend Policy: John Wiley \& Sons, pp. 115-126. 
[33] Smith, David M. (2009). Residual Dividend Policy, In H. Kent Baker (ed). Dividends and Dividend Policy, pp. 115-126. Hoboken, NJ: John Wiley \& Sons.

[34] Frank, Murray and Goyal, Vidhan (2003). Testing the Pecking Order Theory of Capital Structure, Journal of Financial Economics, Vol. 67 (2), pp. 217-248.

[35] Aggarwal, Raj and Kyaw, Aung NyoNyo (2010). Capital Structure, Dividend Policy and Multinationality: Theory Versus Empirical Evidence, International Review of Financial Analysis, Vol. 19 (2), pp. 140-150.

[36] Baker, H. Kent and David M. Smith. (2006). "In Search of a Residual Dividend Policy." Review of Financial Economics, Vol. 15(1), pp. 1-18.

[37] Lintner, John (1962). Dividends, Earnings, Leverage, Stock Prices and Supply of Capital to Corporations, The Review of Economics and Statistics, Vol. 64, pp. 243-269.

[38] Gordon, Myron J. and Shapiro, Eli (1956). Capital Equipment Analysis: The Required Rate of Profit, Management Science, Vol. 3, pp. 102-110.

[39] Frankfurter, George M. and Bob, G. Wood (2002). Dividend Policy Theories and Empirical Tests, International Review of Financial Analysis, Vol. 11, pp. 111-138.

[40] Laiboni, M. (2013). Dividend Theories. [online] Available at: http://www.slideshare.net/ice456/dividend-theories [Accessed 9 May 2015].

[41] Shackelford, A. Douglas, (2001). Stock Market Reaction to Capital Gains Tax Changes: Empirical Evidence from the 1997 and 1998 Tax Acts. Tax Policy and the Economy, Vol. 14(1), pp. 67-92.

[42] Altman, Edward I. (2000). Predicting Financial Distress of Companies: Revisiting the Z-Score and Zeta models, New York University.

[43] Fama, E.F., Fisher, L., Jensen, M.C. and Roll, R. (1969). The Adjustment of Stock Prices to New Information, International Economic Review, Vol. 10, pp $1-21$.

[44] Wang, Y., Wang, W. C., and Wang, J. J. (2017). Credit Risk Management Framework for Rural Commercial Banks in China. Journal of Financial Risk Management, Vol. (6), pp. 48-65.

[45] Altman, E. (1968). "Financial Ratios, Discriminant Analysis and the Prediction of Corporate Bankruptcy," Journal of Finance, Vol. 23(4), pp 589-609.

[46] Altman, E., Hartzell, J. and Peck, M. (1995). Emerging Markets Corporate Bonds: A Scoring System, Salomon Brothers Inc, New York, USA.

[47] Myers, M. D. (2013). Qualitative Research in Business and Management. New Delhi, ND: Sage Publications Ltd.

[48] Kothari, C. R. and Garg G. (2014). Research Methodology. Methods and Techniques, $3^{\text {rd }}$ Ed. New Age International Publishers: New Delhi.

[49] Dawson, J.F. (2014). Moderation in Management Research: What, Why, When and How. Journal of Business and Psychology, Vol. 29 pp 1-19.

[50] Kombo, D.K., and Tromp, D.L.A. (2013). Proposal and Thesis Writing: An Introduction. Paulines Publications Africa, Don Bosco Printing Press, Nairobi Kenya. 
[51] Polit, D. and Beck, C. (2017). Nursing Research: Generating and Assessing Evidence for Nursing Practice, $10^{\text {th }}$ Edition, Wolters Kluwer: Lippincott, Williams \& Wilkins, Philadelphia. Baltimore. New York. London.

[52] Grove, S.K., Burns, N. and Gray, J.R. (2014). Understanding Nursing Research: Building and Evidence-Based Practice. Elsevier Health Sciences. Philadelphia: Wolters Kluwer/Lippincott Williams \& Wilkins.

[53] Cooper, R. D. and Schindler P. S. (2014). Business Research Methods. $12^{\text {th }}$ Edition. McGraw-Hill Education. New York.

[54] Williams, M.K. (2006). Research Methods Knowledge Base, http://www.socialreserachmethod.net.

[55] Jarque, C.M. and Bera, A.K. (1987). A Test for Normality of Observations and Regressions Residuals. International Statistical Review, Vol. 55 pp. 163-172.

[56] Levin, A., Lin, C., \& Chu, C. (2002). Unit Root Test in Panel Data: Asymptotic and Finite Sample Properties. Journal of Econometrics, Vol. 108 (1), pp. 1-24.

[57] Im, K. S., Pesaran, M. H., \& Shin, Y. (2003). Testing for Unit Roots in heterogeneous Panels. Journal of Economics. Vol. 115, pp. 53-74.

[58] Dickey, D.A and Fuller, W.A. (1981). The Likelihood Ratio Statistics for the Autoregressive Time Series With a Root Test, Economic Review, Vol. 49, pp. $1057-1072$.

[59] Plackett, R.L. and Pearson, K. (1983). The Chi-squared Test. Int. Statist. Vol. 51, pp. 59-72.

[60] Hausman, J.A. (1978). Specification Tests in Econometrics. Econometrica, Vol. 46 pp 1251-1271.

[61] Fama, E.K. (1965). The Behaviour of Stock Market Prices. Journal of Business, Vol. 38, pp. 34-105. 